FOCUS: Journal of International Business Volume 4, Issue 1, January-June 2017, pp. 38-52 doi: 10.17492/focus.v4i01.9538

\title{
An Empirical Study of Financial Integration between Stock Market of India and Australia
}

\author{
Amit Kumar Singh* and Rohit Kumar Shrivastav**
}

\begin{abstract}
Growth of a country is dependent upon growth of industries which, in turn, depends upon capital market conditions because this market is going to give an element which is most important for the success and failure of every industry i.e., funds. The Australian Securities Exchange market is the largest exchange in the world with market capitalisation of more than $A \$ 1.5$ trillion. It is the finest and most advanced and automated exchange of the world. India is also having sophisticated stock exchange which is National Stock Exchange. The present paper made an attempt to investigate financial integration between NSE and ASX stock market taking daily closing index of ASX and NSE. The descriptive statistics showed NSE market provides slightly higher returns than ASX market. The results of Granger causality show that ASX does not Ganger cause return at NSE and NSE also does not Granger cause return at ASX. The Johansen Co-integration test also speaks about no co-integration between them. Therefore, during the study we did not find a strong financial integration between both the nations'stock market.
\end{abstract}

Keywords: Stock Market; Integration; Granger causality; Johansen co-integration test India; Australia.

\subsection{Introduction}

Growth of a country is dependent upon growth of industries in the country which, in turn, depends upon conditions of capital market of the country because this market is going to give an element which is most important for the success and failure of every industry i.e., funds.

*Corresponding author; Associate Professor, Department of Commerce, Delhi School of Economics, University of Delhi, Delhi, India. (Email id: amitipo10@gmail.com)

**Ph. D. Research scholar, Department of Commerce, Delhi School of Economics, University of Delhi, Delhi, India. (Email id: rohitkshrivastav@gmail.com) 
Funds work as a life blood for an industry, more particularly for a company. The capital market helps the companies to raise funds for satisfying their fund requirement need. Basically, capital market of a country works as a channel for creating demand and supply of the debt and equity capital. It has always been a key part of overall financial system of every economy. On one hand, primary market helps raising the funds for long-term requirements of corporates and institution and on the other, secondary market provides buying and selling the securities already issued in primary market and hence provides liquidity to investors. This market not only boost growth of different sectors of economy but also channelise the surplus funds (savings) to the deficient fund (borrowings) units of society and thereby enables the optimum allocation of capital resource scarce in nature thus provide the long-term funds for sustainable economic growth. As we know that, a sound and efficient stock market is now need of the hour for increasing growth of economy manifold therefore, the focus has been shifted now on establishment of variables which determine the stock returns.

Australia and India are having trade and political relations even before the independence of India. Before the independence, India and Australia both were the part of British Empire. Now both are members of the Commonwealth of Nations. Both share political, economic, security, lingual and sporting ties too. Due to the British colonisation, cricket has emerged as a strong cultural connection between these two nations and the English language too. There is a regular joint naval exercise named as AUSINDEX between Australia and India. According to some studies, prior to the colonisation of Australia, around 4,000 to 5,000 years ago evidences have been found for ancient migration of Indians to Australia based on DNA and the language development in native Indians and Indigenous Australians. The very bonding between them started immediately following the European settlement of Australia in 1788. It was also been observed that after founding of penal colony of New South Wales all trade to and from the colony was basically controlled by the British East India Company.

After the World War II, the then Australian government supported India's Independence from the British Empire for acting as a frontier against communism. Later on Australia supported admission of Indian country as a Republic to the Commonwealth Nations. Later in 1950, Robert Menzies (who supported India's admission to commonwealth nations) became first Australian Prime Minister to visit India and met the Governor-General Chakravarti Rajagopalachari and Prime Minister Jawaharlal Nehru. Besides members of Commonwealth of Nations, both the countries are also the founding members of United Nations and also the members of the regional organisations including ASEAN Regional forum and Indian Ocean Rim Association for Regional Cooperation. 
Australia always supported India's position on Arunachal Pradesh, which is basically subject to the diplomatic disputes between People's Republic of China and India.

Talking about the economic relations, India was Australia's first major trading partner with imports through the East India Company and exports of coal from Sydney and horses from New South Wales are also dates back to lath 18th and early 19th century. In 2003, the bilateral trade between them amounted to $\mathrm{A} \$ 4.3$ billion and as per the recent regard, the bilateral trade has now reached to more than $\mathrm{A} \$ 22$ billion in 2016. Australian exports included coal, vegetables and gold, and Indian exports included refined petroleum, medicines and business services. Not only that Australia and India have established a A $\$ 100$ million Strategic Research Fund. After a series of attempts by prime ministers of all parties John Howard, Kevin Rudd, Julia Gillard, and Tony Abbott eventually in 2016 under Malcolm Turnbull, both the Australian political parties opened the door for uranium exports to India potentially starting in 2017.

Australia and India are not neighbouring countries but still they enjoy good economic and political relations for years. On one hand, India enjoys strategic position in Asia region and on the other Australia is perceived as the global economy of the world. This paper made an attempt to explore existence of dynamic inter-linkages and causal relationship between ASX and NSE market and further identifying scope of integration between ASX and NSE market due to establishment of long-term relations between both the countries and to know whether there is any significant impact on market of these countries even if they have a good relations in trade and politics.

\subsection{An Overview of the Indian and Australian Stock Market}

\subsection{National Stock Exchange (NSE)}

In India, there are basically two leading stock exchanges: the National Stock Exchange of India Limited (NSE) and Bombay Stock Exchange (BSE). For this paper, only NSE has been taken as it is being considered as the real barometer with the market capitalisation of US $\$ 1.65$ trillion and ranked $12^{\text {th }}$ in the world. NSE, established in 1992 , being India's first demutualized electronic exchange, not only provides more modern and screen-based fully-automated trading system but also makes the trading facility easier to investors who are spread across India. NSE's flagship index is CNX Nifty which incorporates 50 stocks in index, which is used by the investors extensively in and around India and world for analysing the Indian capital markets. NSE is having state of-the-art application with record up time of $99.99 \%$ which processes messages around 450 million daily having sub millisecond response time. 


\subsection{Australian Securities Exchange (ASX)}

Australian Securities Exchange (ASX), one of the world's top 15 listed stock exchanges, was formed in April 1986 and merged in 2006 with Sydney Futures Exchange. It is having a daily turnover of more than $\mathrm{A} \$ 4.5$ billion and market capitalisation of more than $\mathrm{A} \$ 1.5$ trillion. It has been one of the world's leading financial market exchanges which offer full range of services including trading, settlement, listings, clearing and across a comprehensive range of the asset classes. It is considered as the leader in the world for raising capital and thereby consistently ranking among top 5 exchanges globally. Its more than $\$ 47$ trillion interest rate derivatives market is largest in Asia. Its network and data centre are connected to leading financial hubs. Speed, reliability, state-of-the-art technology and diversity of the user community, are fundamental for the success of Sydney-based ASX Australian Liquidity exchange Centre. ASX is having more than 150 years of exchange experience with 530 people as a team of highly skilled persons. Its major benchmark index is S\&P/ASX 200 and the Australian Securities and Investment Commission (ASIC) has responsibility of supervising real-time trading on financial markets of Australia and supervision of the conduct by participants. For the purpose of financial system stability, the Reserve Bank of Australia (RBA) has oversight of ASX's clearing and settlement facilities. It has many participating securities such as equity, bond, derivatives, foreign exchange etc.

\subsection{Review of Literature}

This section reviews existing literature in this area and the results drawn therefrom. Chaudhuri (1997) investigated the relation among six Latin American countries for the period of $1985-1993$ by using the Engle-Granger, Granger causality and co-integration and found long-term relationship among all the six Latin America country's group. Bekaert and Harvey (2000) and Karolyi (1996) investigated the timevarying linkages among the different international stock markets and they found that when there is a dominance of global factors on domestic factors, a possibility of increase in the correlation. In addition to this, many authors documented that the correlations are found to be higher when the markets simultaneously go down which further reduces insurance effect from the international diversification as per the study of Longin and Solnik (2001). Using matched sample design where the companies are matched by the size and the industry from countries like Canada, Australia and US capital markets, Faff and Mittoo (2003) investigated that whether integration of capital market varies across industries and the geographical proximity. The study was conducted from 1983 to 1997 period and the multi-factor pricing framework was tested. Results of the study support 
pricing of Australian stocks being different from the Canadian and U.S. counterparts. Mukherjee (2007) captured the similarities, patterns and trends in activities and movements of Indian Stock Market in comparison to its international counterparts. The study covered Tokyo Stock exchange (TSE), Hong Kong Stock exchange (HSE), Russian Stock exchange (RSE), New York Stock Exchange (ASX) and Korean Stock exchange (KSE) from the backdrop of socio- politico-economic backgrounds. As a part of Indian stock market, both BSE and NSE were used. Study conducted with correlation and regression, from January 1, 1995 to July 31, 2006 by comparing the different parameters viz; market capitalisation, number of listed securities, listed agreements, circuit filters and settlement to testify that the Indian markets have become much integrated with its global counterparts. The findings showed that the stock markets do impact each other, more so in the recent times, i.e. post-2000.

Chittedi (2009) examined integration of BRIC economies and further their integration with the developed countries markets such as the UK, Japan and US using Johansen's cointegration, Granger's causality and Error Correction Mechanism/Model (ECM). It was found that there is cointegration between BRIC countries and developed countries, namely, the USA, UK, and Japan. The results of ECM revealed that the NIKKEI, SENSEX, BOVESPA and FTSE are significant. It infers that these markets share forces of short-run adjustment to long-run equilibrium. Singh and Singh (2010) examined the linkages between two leading emerging markets of the world namely China and India and the developed markets (United States, United Kingdom, Japan and Hong Kong) using the daily closing index data from January 2000 to December 2009. The linkages were modelled using correlation test, Granger causality and the cointegration test. It was found that Chinese and Indian markets are both correlated with all four major markets. Both markets have at least had a unilateral causality with all four developed markets. Their study suggested the benefits of any short-term diversification, or speculative activities, are limited between them. Marimuthu (2010) examined comovements among the stock markets of Malaysia, India, China, US and UK. Study found bidirectional causality between Malaysia and India. Study also concluded that US market dominated all Asian markets. The study conducted by Sheu and Liao (2011) analysed rising pattern of integration and causal relationships among BRIC's stock markets and US market. Their empirical study showed that stock markets of Russia, China and Brazil have started exerting significant influences on the US Dow Jones exchange to some extent after the period of 2006 and Dow Jones index has continued to play a vital and dominant role in Granger causing shifts in the emerging markets of India, China and Russia. Their findings indicated the time-varying nature of the nonlinear Granger causality and co-integration relationships and apart from that it also 
indicated that the potential benefits from international risk diversification may have gradually diminished within these groups of markets.

Vieito, Bhanumurthy and Tripathi (2013) tried to explore weak-form efficiency in most developed countries of the world (G-20) along with measuring impact of 2007 financial crisis in markets of these countries, in terms of efficiency. They explored the emergence of strong contemporaneous effects across all international markets (barring Saudi Arabia) consequence of 2007 crisis may be just because of intra-day activity increment international across world markets. They found market index was inefficient while the individual stocks were efficient. Palamalai et al. (2013) analysed the stock market integration among the major stock markets of the emerging Asia-Pacific economies, namely India, Hong Kong, Malaysia, Singapore, Taiwan, Japan, South Korea, Indonesia and China. They adopted Johansen Cointegration test which confirmed a well-defined long-run equilibrium relationship among the major stock markets which further imply an existence of common force like arbitrage activity that is responsible for bringing these markets together in the long term. The results of Granger causality/Block exogeneity Wald test based on VECM and variance decomposition analysis revealed the stock market interdependencies and dynamic interactions among the selected emerging Asia-Pacific economies. Finally they concluded that investors can gain feasible benefits from international portfolio diversification in the short run. The study further suggests that although the long-term diversification benefits from the exposure to these markets might be limited but the short-run benefits might prevail due to the substantial transitory fluctuations.

Although the study conducted by Bhanumurthy and Singh (2014) evaluated the short-run IPOs' performance but they also revealed that the performance of the IPOs also affect the return of stock index (though in short-run). So, the stock index returns of different markets are also influenced by the IPOs introduced in their respective economy. Paramati et al. (2015) tried to explore the extent and manner of stock market interdependence between Australia and its trading partners and further examining whether it is affected by trade intensity. They hypothesised that markets with greater (lower) trade intensity will be more (less) interdependent with Australia. With the application of correlation (unconditional and conditional) analyses between Australia and its trading partners they found that most of the markets which are highly correlated with Australia are its major trading partners. They further applied panel regression analysis to investigate impact of trade intensity on the stock market correlations between Australia and its trading partners. They concluded that trade intensity significantly and positively affect the correlations of Australia with its major trading partners. 
Choudhary and Siag (2015) tried to explore the short run linkages and long run linkages among the major developed equity markets. They found that there is linkages in short run among major developed equity markets. However considering the long term integration, they explored that there is contradictions among the results of the various studies. Although they reviewed that there is no robust result which supports the long term integration. Singh and Shrivastav (2016) made an attempt to investigate the inter linkages and inter relationships between Sri Lanka and India's stock market. They tried to identify scope of integration between Sri-Lanka and India's stock market due to establishment of the long-term relations between both the countries. They applied ADF test for checking stationarity of data. Correlation between the indices of India and Sri Lanka is coming out to be +0.545507 . Testing results of Granger Causality explained that return at Colombo exchange does not Granger Cause return at Indian stock exchange and vice versa. Johansen Co-integration test also speaks about no co-integration between them. Therefore, even though good relationship exists between these nations still stock market of both the nations are not integrated towards each other. Babu et al. (2016) aimed to study the linkages of Asia Pacific stock markets including Australian Stock Exchange, BSE India, Shanghai Stock Exchange, Hong Kong Exchange and Tokyo Stock Exchange with the use of daily index price from April 2009 to March 2014. K-S test, ADF Test, and Phillips-Perron Statistic were used to test normality and existence of the unit root in data. They applied Johansen Trace-Statistic and Max-Eigen statistic to find the effect of causation of the sample indices. Their findings revealed existence of long run relationships in Asia Pacific stock market indices.

\subsection{Objectives of the Study}

The paper talks about inter-linkages and relationship between Indian and Australian securities exchange markets. The specific objectives of the study are as under: The primary objective of the study is to analyse degree of interdependence and impact between Australian and Indian securities market. The secondary objectives are as follows:

- To correlate the performance of Australia and Indian securities market.

- To examine the scope of integration between Australia and Indian securities market.

\subsection{Research Design and Methodology}

\subsection{Data}

This article is an attempt to explore inter-linkages between Australian exchange and Indian (NSE) market and to find the new dimensions of linkages and integration 
between these markets. The study was conducted for a 6 year period starting from January 1, 2011 to December 31, 2016 for evaluating existence of dynamic relationship. We have taken one stock exchange from both the countries. Australian Securities Exchange (ASE) has been taken as the representative exchange for Australia. While India has two leading stock exchanges National Stock Exchange (NSE) and Bombay Stock Exchange (BSE), we opted only for NSE (CNX Nifty Index) as the representative exchange of India.

The daily closing stock index price value has been taken starting from January 2011 to December 2016 considering as the reference period, in this way, the data of the 72 months gathered to testify existence of inter-linkages between NSE and ASX. For the days when either of stock exchanges is closed, Indian market is considered as the base and accordingly missing values were found out. The data is mainly collected from ASX website, NSE website, Yahoo finance, Moneycontrol.com, Investing.com and websites of the various agencies of respective government and annual reports. Secondary data and other pertinent literature available on this subject had been compiled from published/unpublished materials, documents and internet sources through extensive desk work. The data analysis was done with EViews 9.

\subsection{Econometric Techniques}

The descriptive statistics (mean, median, mode, standard deviation, skeweness, kurtosis) have been used to summarise the general trend and pattern of the dataset. For checking data series stationarity, which is essential for enhancing reliability and accuracy of the model, we prepared the line graph of each series. Time series data is called stationary if the mean, variance and auto-covariance are independent of time. We have used the log value of indices and further testified the nature of data series with the application of Augmented Dickey-Fuller (ADF) test under unit root hypothesis testing with below mentioned equation.

$$
\Delta \mathrm{yt}=\alpha+\beta \mathrm{t}+\gamma \mathrm{yt}-1+\delta 1 \Delta \mathrm{yt}-1+\cdots+\delta \mathrm{p}-1 \Delta \mathrm{yt}-\mathrm{p}+1+\varepsilon \mathrm{t}
$$

where $\alpha$ is referred as constant, $\beta$ time trend coefficient and $\mathrm{p}$ being lag order of autoregressive process. Imposing constraints $\alpha=0$ and $\beta=0$ corresponds random walk modeling and use of constraint $\beta=0$ corresponds modeling the random walk with drift.

After ADF test, we applied Johansen Co-integration in indices of ASX and NSE and estimated the correlation value and after finding it test of Granger causality was conducted on NSE and ASX index return for capturing the degree and the direction of causation between India and America stock price indices under study and to further explore the short and the long-run interrelationships and integration between these stock markets. 


\subsection{Data Analysis and Interpretation}

The data is statistically evaluated and interpreted in this section for indices of ASX and NSE. Starting with descriptive statistics as shown in Table 1, the results obtained for the same depicts that ASX Index is negatively skewed which means tail of distribution is on left or distribution is having a long left tail and concentration of mass distribution is on right. In case of NSE index (India) positively skewed which means tail of distribution is on right or distribution is having a long right tail and the concentration of mass distribution is on the left. The kurtosis, in normal distribution series, has a value of 3. Since the kurtosis value of NSE and ASX coming out to be less than 3, it infers that these return series are mesokurtic. The mean value of NSE return is 8.792522 whereas the mean value of ASX is 8.510754 which mean Australian market produces little bit lesser return than NSE market.

Table 1: Descriptive Statistics

\begin{tabular}{|c|c|c|}
\hline Statistic & NSE & ASX \\
\hline Mean & 8.792522 & 8.510754 \\
\hline Median & 8.727689 & 8.538769 \\
\hline Maximum & 9.104563 & 8.696625 \\
\hline Minimum & 8.421607 & 8.259430 \\
\hline Std. Dev. & 0.197097 & 0.104936 \\
\hline Skewness & 0.065308 & -0.460016 \\
\hline Kurtosis & -1.519381 & -0.886604 \\
\hline Jarque-Bera & 142.9162 & 132.9994 \\
\hline Probability & 0.000000 & 0.000000 \\
\hline Observations & 1477 & 1477 \\
\hline
\end{tabular}

To capture the econometric results and its interpretation, two series representing the stock indices of America and India were statistically analysed in EViews 9. Since it is essential to assure series under study is stationary, in econometric analysis, we have used the $\log$ value of indices. The series was tested and found that stationary at first difference. The line graphs are prepared for stationarity. Figure 1 and 2 demonstrate the line graph of Indian and American stock indices returns at first difference. Since it is always good to testify and reconfirm the results with other available tools for having more reliability in the data series, we applied ADF test on the indices of ASX and NSE for unit root. 
Figure 1: Line Graph of NSE Nifty Return

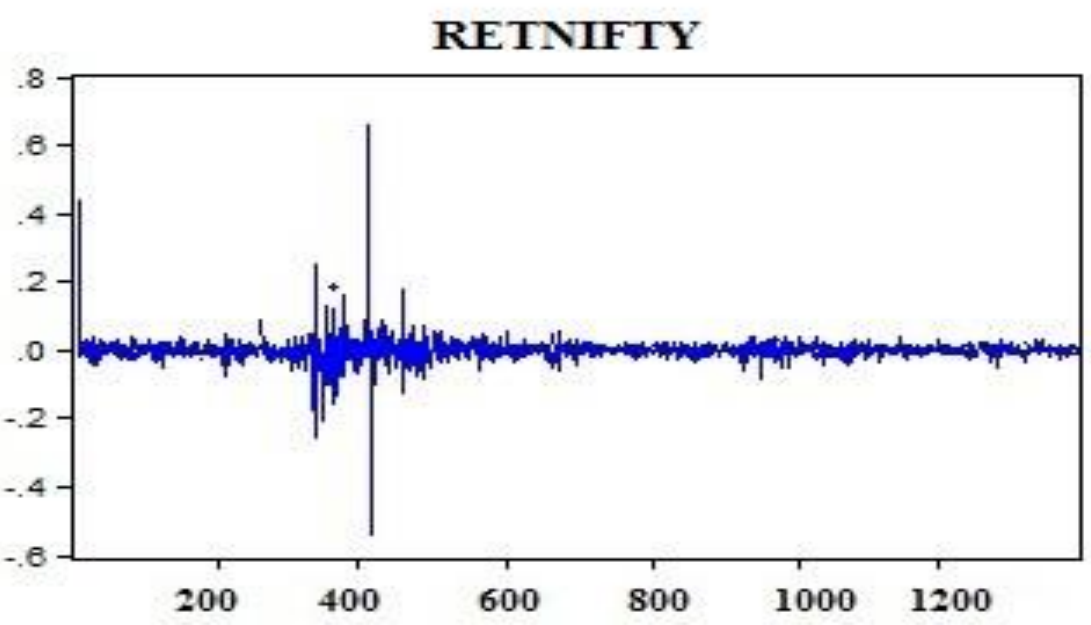

Figure 2: Line Graph of ASX

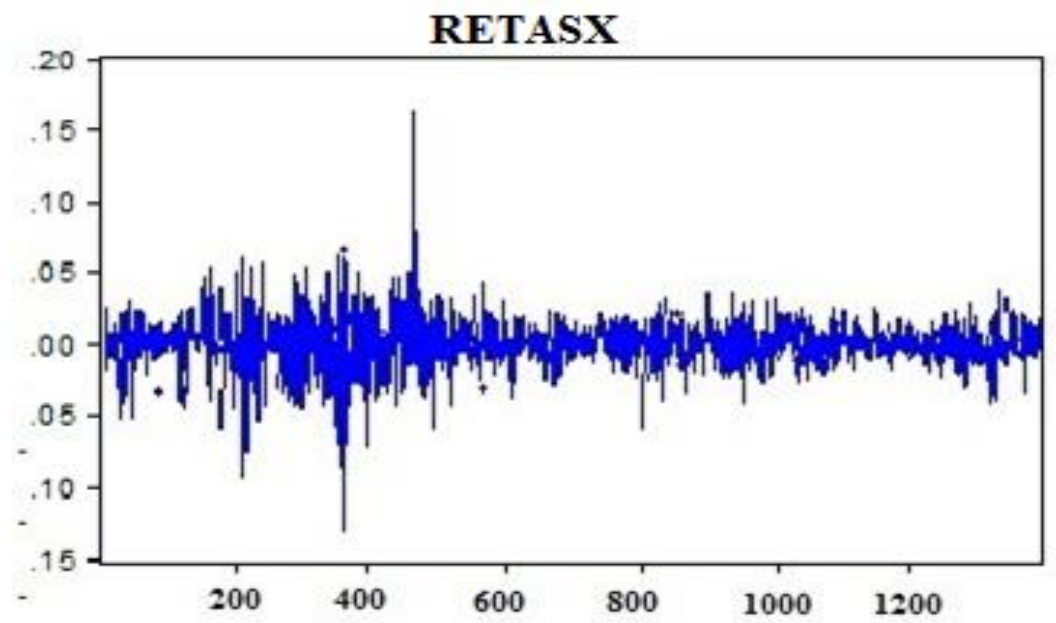

Table 2 and Table 3 represent results of unit root with Augmented Dickey-Fuller test. We tested the null hypothesis that data series has a unit root, at 5\% significance level. The series was found that non-stationary at level but stationary at first difference. 
48 | FOCUS: Journal of International Business, Volume 4, Issue 1, January-June 2017

Table 2: ADF Results for NSE Index

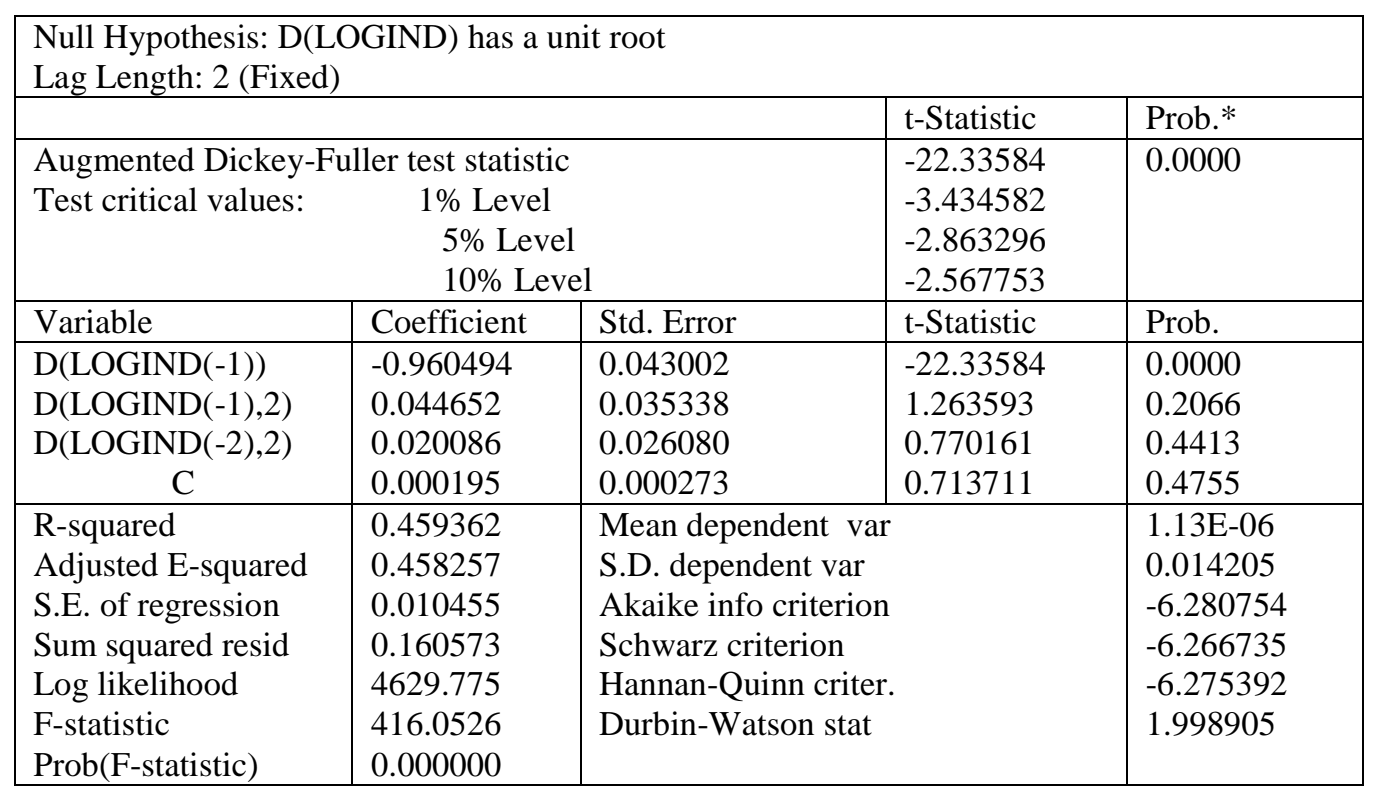

Table 3: ADF Results for ASX

\begin{tabular}{|c|c|c|c|c|}
\hline \multicolumn{5}{|c|}{$\begin{array}{l}\text { Null Hypothesis: D(LOGASX) has a unit root } \\
\text { Lag Length: } 2 \text { (Fixed) }\end{array}$} \\
\hline & & & t-Statistic & Prob.* \\
\hline \multicolumn{3}{|c|}{ Augmented Dickey-Fuller test statistic } & -37.98101 & 0.0000 \\
\hline \multirow[t]{3}{*}{ Test critical values: } & \multirow{3}{*}{\multicolumn{2}{|c|}{$\begin{array}{l}1 \% \text { Level } \\
5 \% \text { Level } \\
10 \% \text { Level }\end{array}$}} & -3.434576 & \\
\hline & & & -2.863293 & \\
\hline & & & -2.567752 & \\
\hline Variable & Coefficient & Std. Error & t-Statistic & Prob. \\
\hline D(LOGASX(-1)) & -0.989471 & 0.026052 & -37.98101 & 0.0000 \\
\hline $\mathrm{D}(\operatorname{LOGASX}(-1), 2)$ & 0.054782 & 0.045338 & 1.363593 & 0.2166 \\
\hline $\mathrm{D}(\operatorname{LOGASX}(-2), 2)$ & 0.014856 & 0.036080 & 0.880161 & 0.4313 \\
\hline $\mathrm{C}$ & 0.000145 & 0.000243 & 0.453046 & 0.4455 \\
\hline R-squared & 0.494779 & \multicolumn{2}{|c|}{ Mean dependent var } & $1.53 \mathrm{E}-06$ \\
\hline Adjusted E-squared & 0.494436 & \multicolumn{2}{|c|}{ S.D. dependent var } & 0.012926 \\
\hline S.E. of regression & 0.009191 & \multicolumn{2}{|c|}{ Akaike info criterion } & -6.539912 \\
\hline Sum squared resid & 0.124421 & \multicolumn{2}{|c|}{ Schwarz criterion } & -6.532730 \\
\hline Log likelihood & 4825.185 & \multicolumn{2}{|c|}{ Hannan-Quinn criter. } & -6.537234 \\
\hline F-statistic & 1442.557 & \multirow{2}{*}{\multicolumn{2}{|c|}{ Durbin-Watson stat }} & 2.000433 \\
\hline $\operatorname{Prob}($ F-statistic) & 0.000000 & & & \\
\hline
\end{tabular}


We then applied Ganger causality test and found that for the hypothesis RETASX does not Granger Cause RETNSE, the probability value was more than 0.05 indicating the acceptance of null hypothesis. We, thus infer that ASX does not affect return on NSE. For the hypothesis, RETNSE does not Granger Cause RETNSE, again the probability value was found to be more than 0.05 which infers NSE does not affect ASX.

Table 4: Granger Causality Test Results

\begin{tabular}{|l|l|l|l|l|}
\hline Null Hypothesis & Observations & F-Statistics & Prob. & $\begin{array}{l}\text { Causal } \\
\text { Relationship }\end{array}$ \\
\hline $\begin{array}{l}\text { RETNSE does not Granger } \\
\text { Cause RETASX }\end{array}$ & 1477 & 2.67555 & 0.0692 & No \\
\cline { 1 - 3 } $\begin{array}{l}\text { RETASX does not Granger } \\
\text { Cause RETNSE }\end{array}$ & & 3.31696 & 0.0610 & No \\
\hline
\end{tabular}

We applied Johansen Co-integration test, after Granger causality, for evaluating stock market co-integration between them. It is clear from the results that since trace statistic is less than critical value and p-value is also coming out to be more than 0.05 therefore we accept null hypothesis, no co-integration between stock market of India and Australia.

\subsection{Conclusion}

The Australian Securities Exchange (ASX) and National Stock Exchange (NSE) are two fully automated exchanges of world and ASX is ranked in top 15 world's listed exchange group for market capitalization. India (NSE) is also ranked $12^{\text {th }}$ in the global stock exchanges. Although, India and Australia are not neighbouring countries but still have a good trade, economic and political relationship from years. This paper tried investigation of financial interdependence between NSE and ASX with stock index comovement and with the use of various econometric tests.

We applied ADF test for checking usability of data series for econometric test and found data series non-stationary at level but stationary at first difference. Descriptive statistics showed that stock market of India provide lower returns in compare of Australian Securities Exchange market Correlation between the indices of ASX and India is coming out to be +0.825222 which depicts stock market of India is correlated with the ASX Market. The results of Granger Causality explained that return at ASX 
does Granger Cause return at Indian exchange, implying that the returns on NSE is influenced more with ASX index co-movements but this is not the case with NSE because NSE does not Granger Cause return at ASX. Johansen Co-integration also speaks about no co-integration between them. Therefore, our concluding remark is that while India and Australia share good relations in a number of areas, there is weak evidence of financial integration between their stock markets.

Table 5: Co-integration results of NSE and ASX

\begin{tabular}{|c|c|c|c|c|}
\hline \multicolumn{5}{|c|}{$\begin{array}{l}\text { Trend assumption: Linear deterministic trend } \\
\text { Series: LOGIND LOGAUS } \\
\text { Lags interval (in first differences): } 1 \text { to } 4\end{array}$} \\
\hline \multicolumn{5}{|c|}{ Unrestricted Cointegration Rank Test (Trace) } \\
\hline $\begin{array}{l}\text { Hypothesized } \\
\text { No. of CE(s) }\end{array}$ & Eigenvalue & $\begin{array}{c}\text { Trace } \\
\text { Statistics }\end{array}$ & $\begin{array}{c}0.05 \\
\text { Critical Value }\end{array}$ & Prob.** \\
\hline $\begin{array}{l}\text { None } \\
\text { At most } 1\end{array}$ & $\begin{array}{l}0.008522 \\
0.000462\end{array}$ & $\begin{array}{l}13.27862 \\
0.680391\end{array}$ & $\begin{array}{l}15.49471 \\
3.841466\end{array}$ & $\begin{array}{l}0.1050 \\
0.4095\end{array}$ \\
\hline \multicolumn{5}{|c|}{$\begin{array}{l}\text { Trace test indicates no cointegration at the } 0.05 \text { level } \\
* \text { denotes rejection of the hypothesis at the } 0.05 \text { level } \\
* * \text { MacKinnon-Haug-Michelis (1999) p-values }\end{array}$} \\
\hline \multicolumn{5}{|c|}{ Unrestricted Cointegration Rank Test (Maximum Eigenvalue) } \\
\hline $\begin{array}{l}\text { Hypothesized } \\
\text { No. of CE(s) }\end{array}$ & Eigenvalue & $\begin{array}{c}\text { Trace } \\
\text { Statistics }\end{array}$ & $\begin{array}{c}0.05 \\
\text { Critical Value }\end{array}$ & Prob.** \\
\hline $\begin{array}{l}\text { None } \\
\text { At most } 1\end{array}$ & $\begin{array}{l}0.008522 \\
0.000462\end{array}$ & $\begin{array}{l}12.59823 \\
0.680391 \\
\end{array}$ & $\begin{array}{l}14.26460 \\
3.841466 \\
\end{array}$ & $\begin{array}{l}0.0902 \\
0.4095 \\
\end{array}$ \\
\hline
\end{tabular}

Since both the countries are Commonwealth members therefore sports and cultural ties are seen as very important. Although there has been some word of clash relating to Uranium sales to India but it was resolved by Labour Party decision in Australian Parliament. The Indian and Australian militaries have also worked well together. Even historically both the nations are very close to each other. Although all these commonalities are seen between these two countries, the stock markets of NSE and ASX are not found to be financially integrated with each other. Although, Granger causality speaks about causal relationship of ASX and NSE but that could not be the only tool for having a broader picture of relationship between them. There is further 
scope of studying existence of long run relationship between both the nations by taking more years into consideration.

\section{References}

Babu, M., Hariharan, C. \&, Srinivasan, S. (2016). Inter linkages of Asian Pacific stock markets: An empirical study. Amity Journal of Finance, 1(1), 48-56.

Bekaert, G., \& Harvey, C.R. (1995). Time-varying world market integration. The Journal of Finance, 50(2), 403-444.

Bhanumurthy, K. V., \& Singh, A. K. (2014). Short run performance of IPO Market in India. International Journal of Financial management, 2(4), 11-22.

Bhole, L.M., \& Mahakud, J. (2009). Financial institution and markets $\left(5^{\text {th }}\right.$ ed.). New Delhi: Tata McGraw-Hill Publishing Company.

Chaudhuri, K. (1997). Cointegration, error correction and Granger causality: An application with Latin American stock markets. Applied Economic Letters, 4, 469-471.

Chittedi, K.R. (2009). Global stock market development and integration: With special reference to BRIC countries. International Review of Applied Financial Issues and Economics, 2(1): 3-21.

Choudhary, S. \&, Siag, R. (2010). Stock market interlinkages among major developed equity markets: Critical literature review. International Journal of Applied Research, $1(4), 87-91$.

Faff, R.W, \& Mittoo, U. R. (2003). Capital market integration and industrial structure: The case of Australia, Canada and the United States. Journal of Economic Integration, 18(3), 433-465.

Korajczyk, R.A. (1996). A measure of stock market integration for developed and emerging markets. The World Bank Economic Review, 10(2), 267-289.

Longin, F. \& Solnik, B. (1995). Is the correlation in international equity returns constant: 1960-1990? Journal of International Money and Finance 14, 3-26. 
52 FOCUS: Journal of International Business, Volume 4, Issue 1, January-June 2017

Marimuthu, M. (2010). The co-movements of the regional stock markets and some implications on risk diversification. The IUP Journal of Applied Economics, 9(2), 61-80.

Mukherjee, D. (2007). Comparative analysis of Indian stock market with international markets. Great Lakes Herald, 1(1), 39-71.

Paramati, S. R., Gupta, R. \&, Roca, E. (2015). Stock market interdependence between Australia and its trading partners: Does trade intensity matter? Griffith Business School (Discussion Papers), No. 2015-06.

Palamalai, S., M., K. \&, Devkumar, C. (2013). Stock market linkages in emerging AsiaPacific Markets. SAGE Open, 3(4), 1-15.

Sheu, H.J., \& Liao C.H. (2011). Dynamics of stock market integration between the US and the BRIC. African Journal of Business Management, 5(9): 3674-3689.

Singh, A. K. \&, Shrivastav, R. K. (2016). Study of inter-linkages and inter-dependence between stock market of India and Sri Lanka. Business Analyst, 37(2), 197-207.

Singh, G. \&, Singh, P. (2010). Chinese and Indian stock market linkages with developed stock markets. Asian Journal of Finance \& Accounting (Macrothink Institute), 2(2), 2139.

Vieito, J.P., Bhanumurthy, K.V., \& Tripathi, V. (2013). Market Efficiency in G-20 Countries: The Paradox of Financial Crisis. Annals of Financial Economics, 8(1), 1-27. 